\title{
POLITYKA SPOŁECZNA I RYNEK PRACY 4.0 A PRZYSZŁOŚĆ PRAWA PRACY, CZYLI AKSJOLOGICZNY I PRAGMATYCZNY WYMIAR WYZWAŃ W PRACACH NAD NOWYM KODEKSEM PRACY
}

\author{
Abstract \\ Social policy and the labor market 4.0 and the future of labor law - the axiological and \\ pragmatic dimension of challenges in the work on a new labor code
}

The need to codify labor law has long been invoked and emphasized by employers and employees. From the beginning of transformation, Poland has made changes towards compliance with EU law. However, no changes in collective labor law have been initiated. The changes that the world of work of the era of Fordism undergo, which together with the new technology and progressive globalization, have profound changes in the work and the labor market itself. Employment in traditional branches of industry decreased, the concentration of employees decreased, while the number of employees in the sector of small and medium enterprises increased. Parallel to these processes, labor markets are characterized by high imbalances and, apart from unemployment, the phenomenon of segmentation on the labor market appears. The last significant initiative was the creation in 2016 of the Labor Law Codification Commission, whose aim was to develop individual and collective labor law in 18 months. It does not need to be argued that the 18 -month period of work on two major projects, individual and collective labor law, is too short a time to come to a thoughtful project that would provide a complex view of labor law.

Słowa kluczowe: prawo pracy, zatrudnienie, polityka społeczna, dialog społeczny

Key words: labour law, employment, social policy, social dialoug

\section{Wstęp}

Potrzeba rekodyfikacji prawa pracy jest od dawna przywoływana i podkreślana przez pracodawców i pracowników. Polska od początku transformacji dokonywała zmian w kierunku zgodności z prawem UE. Ukoronowaniem była nowelizacja z 2003 r., poprzedzona negocjacjami partnerów społecznych.

Harmonizacja polskiego prawa pracy z prawem europejskim była niezbyt udana, z elementami krytykowanymi za zakres i sposób harmonizacji, np. przepisy 
antydyskryminacyjne, czas pracy, umowa o pracę. Nie rozpoczęto nawet zmian w zbiorowym prawie pracy. I mimo że wielokrotnie odwoływano się do nieczytelnego i budzącego kontrowersje prawa związkowego, brakowało wizji i odwagi wprowadzenia zmian. Jeszcze większym grzechem zaniechania jest utrzymywanie nieefektywnych regulacji prawa układowego, które w praktyce zamiera na poziomie branżowym, a na poziomie zakładowym przeżywa kryzys. Można i należy sobie postawić kilka pytań, które staną się podstawową osią mojej analizy. Czy związki i oddziaływanie wzajemne polityki społecznej i prawa pracy pozwalają budować efektywny i sprawiedliwy model stosunków pracy? Czy wartości formułowane przez politykę społeczną są skutecznie chronione dzięki oddziaływaniu prawa pracy? Czy prawo pracy radzi sobie z wyzwaniami rozwojowymi wymuszanymi i związanymi z gospodarką 4.0 i dynamicznymi zmianami na rynku pracy? Wreszcie, czy podejmowane próby nowej kodyfikacji są adekwatne do potrzeb, wyzwań i oczekiwań? Jakie problemy wiążą się z kolejną porażką w zakresie kodyfikacji polskiego prawa pracy i czy jej skutki mogą się stać odwracalne?

\section{Wyzwania dla prawa pracy w kontekście zmian w sferze rynku pracy}

W Polsce narastało poczucie niedopasowania ustawodawstwa do potrzeb gospodarki, ale i polityki społecznej, co było zgłaszane zarówno przez pracodawców, związki zawodowe, jak i przedstawicieli doktryny. Przemiany świata pracy w tym ujęciu polegały z jednej strony na odejściu w Europie od powszechnego jeszcze w XX w. modelu fordowskiego do modelu postfordowskiego, charakteryzującego się przechodzeniem od gospodarki industrialnej, opartej na taylorowsko-fordowskiej organizacji pracy, do gospodarki postindustrialnej, od pracy skooperowanej, tj. wykonywanej przez zespoły pracowników zgrupowanych $\mathrm{w}$ jednym miejscu i w tym samym czasie pod nadzorem pracodawcy, do pracy zindywidualizowanej ${ }^{1}$. Przemiany, jakim ulega świat pracy epoki fordyzmu, sprawiają, że wraz z nową technologią i postępującą globalizacją nastąpiły głębokie zmiany samej pracy i rynku pracy, obniżyło się zatrudnienie w tradycyjnych działach przemysłu, zmniejszył się poziom koncentracji pracowników, natomiast wzrosła liczba pracowników sektora małych i średnich przedsiębiorstw oraz zwiększyła się rola usług, zwłaszcza prywatnych ${ }^{2}$. Ale równolegle do tych procesów rynki pracy charakteryzują się dużą nierównowagą i obok bezrobocia pojawia się zjawisko segmentacji na rynku pracy. Szerokie badania nad zjawiskiem nierównowagi na polskim rynku pracy oraz nowymi atypowymi formami zatrudnienia prowadziłem w latach 2006-2007 w Zespole

1 Por. J. Gardawski, Świat pracy a fordyzm i postfordyzm, w: Polacy pracujący a kryzys fordyzmu, J. Gardawski (red.), Warszawa 2009, s. 53 i n.

2 Por. J. Męcina, Wplyw dialogu społecznego na kształtowanie się stosunków pracy w III RP, Warszawa 2011, s. 40-44. 
badawczym „Pracujący Polacy a koniec fordyzmu” oraz w latach 2010-2017 w ramach badań nad dialogiem społecznym i stosunkami pracy³.

Wielu ekspertów podkreśla, że kraje Unii Europejskiej w odpowiedzi na współczesne wyzwania cywilizacyjne i niepowodzenia modelu korporacyjnego w rozwiązywaniu kwestii bezrobocia i zwiększania konkurencyjności gospodarki odchodziły od swoich modeli polityki społecznej lub modyfikowały je przez deregulację gospodarki i uelastycznienie rynku pracy w kierunku neoliberalnych koncepcji ekonomicznych, a pojęcie welfare state zastępowane jest coraz częściej pojęciem workfare state 4 . Procesy dostosowawcze na rynku pracy i zmiany w modelu stosunków pracy stały się nowym wyzwaniem, z którym zwłaszcza w Europie radzono sobie z ogromnymi trudnościami. Na drodze negocjacji i konsultacji między pracodawcami i związkami zawodowymi, a nawet paktów społecznych, wiele państw złagodziło społeczne i ekonomiczne skutki wprowadzenia nowych technologii oraz redukcji niektórych przemysłów. Duży nacisk położono na dostosowywanie prawa pracy do nowych wyzwań, choć jego główne założenia nie zostały zmienione ${ }^{5}$. Druga zmiana technologiczna, która rozpoczęła się pod koniec XX w., a obecnie jest bardzo ekspansywna, polegała na gwałtownym rozwoju technologii informatycznych i komunikacyjnych. Wpłynęla ona mocno na samą istotę i organizację pracy. Zastosowanie na szeroką skalę technologii informatycznych i cyfrowych wywiera wpływ na zmiany ustawodawstwa pracy, reguł wielu elementów dotychczasowych indywidualnych stosunków pracy ${ }^{6}$. Można wymienić najważniejsze zmiany, które dziś są przedmiotem zainteresowania ekspertów, decydentów i partnerów społecznych - pracodawców i związków zawodowych, a które stały się podstawową osią dyskusji i sporów, ale i analiz prowadzonych w Europie i na świecie 7 .

Zdaniem przedstawicieli szkoły regulacyjnej w ekonomii politycznej systemy welfere state i workfere state można traktować jako opozycyjne wobec siebie, w związku z czym przejście od jednego do drugiego reżimu trzeba postrzegać jako radykalną zmianę, określaną mianem „reformy opiekuńczości zorientowanej na pracę” (work-oriented welfare reform $)^{8}$. Przemiana ta, zgodnie z tym nurtem myślenia, dotyczy wszystkich współczesnych modeli polityki społecznej. Wpływ zmian świata pracy na jakość zatrudnienia oraz na rynek pracy jest ważnym wątkiem badań prowadzonych w ostatnich latach. Z perspektywy polityki społecznej prawo pracy powinno ewoluować w kierunku wzmocnienia zatrudnialności pracowniczej, tworzenia mechanizmów przeciwdziałania segmentacji na rynku pracy, zapewnienia prawdziwej dyferencjacji, uwzględniającej

3 Polacy pracujący a kryzys fordyzmu, J. Gardawski (red.), Warszawa 2009.

4 Por. J. Męcina, Wpływ dialogu społecznego...

5 Komisja Europejska, Transformation of labour and future of labour law in Europe, Final Report, Brussels 1998.

6 Por. A. Bronstein, International and comparative Labour Law, Current Challenges, Switzerland 2009, s. 30-57; W. Morawski, Globalizacja i praca. Kontekstowa analiza świata pracy, w: Przyszłość pracy w XXI wieku, S. Borkowska (red.), Warszawa 2004, s. 15-32.

7 Por. J. Męcina, Wplyw dialogu....

8 W. Aniol, Polityka społeczna, Warszawa 2018. 
sytuację pracownika, ale i sytuację pracodawcy, wreszcie powinno wzmacniać wymiar zabezpieczenia społecznego związanego z poszczególnymi ryzykami i efektywność tego systemu.

Wydaje się, że nie można dziś konstruować nowoczesnego prawa pracy bez rozpatrzenia związków tej dziedziny prawa z zabezpieczeniem społecznym, systemem podatkowym, wreszcie przepisami ustawy o promocji zatrudnienia. Tylko wykorzystanie tych wszystkich instrumentów może pozwolić na nowoczesne, ale i bardzo nowatorskie podejście do ochrony pracy, realizowanej już nie tylko w ramach ochronnej funkcji prawa pracy, lecz także korzystającej z dobrodziejstw systemu zabezpieczenia społecznego i ubezpieczeń społecznych, przepisów podatkowych, związanych z opodatkowaniem pracy, wreszcie przepisów o rynku pracy, które dzięki środkom Funduszu Pracy pozwalają na wspieranie zatrudnienia grup najsłabszych, uprawnień pracowników sektora mikroprzedsiębiorstw. Z kolei jeśli patrzymy na wyzwania prawa pracy z perspektywy rynku pracy, można zidentyfikować wiele oczekiwań, w szczególności uwzględnianie nie tylko wyjątkowej sytuacji pracownika, lecz też pracodawcy, zróżnicowanie pracodawców, różnicowanie uprawnień pracowniczych, uwzględnianie szans i zagrożeń związanych z cyfryzacją w stosunkach pracy, zrozumienie istoty permanentnej zmiany na rynku pracy jako wyzwania, przed którym staje pracodawca, a jej skutki dotykają pracowników. Istotne jest także systemowe zapotrzebowanie na kształcenie ustawiczne, przeciwdziałanie dyskryminacji, uzależnienie rynku od zasobów migracyjnych, które wymuszają wzmacnianie prawa pracy innymi politykami publicznymi, towarzyszącymi prawu pracy.

W zarysowanej w ogromnym skrócie analizie, należy odnieść się do głównych pytań konferencji, w pewnym sensie podsumowującej i odnoszącej się do próby kodyfikacji, w której miałem przyjemność uczestniczyć.

\section{Prawo pracy jako instrument kształtowania stosunków pracy i nowe inicjatywy w dziedzinie regulacji}

Praca w ujęciu prawnym jest przede wszystkim definiowana przez prawo pracy. Jego przedmiotem są stosunki pracy podporządkowanej, świadczonej na rzecz drugiego podmiotu dobrowolnie, osobiście i za wynagrodzeniem oraz inne stosunki nierozerwalnie związane ze stosunkami pracy9. Świadczenie pracy ma jednak charakter społeczny, bo pracownik nie tylko realizuje zadania, lecz także jest członkiem zespołu pracowniczego. Polski Kodeks pracy nie definiuje pojęcia praca, prawnicy przyjmują, że praca jest skrótowym określeniem działalności człowieka, którą zajmuje się prawo pracy. Przez pojęcie to rozumie się nie każdą działalność człowieka, która potocznie nazywana jest pracą, robotą czy zajęciem, ale taką działalność człowieka, która polega na zarobkowym wykonywaniu na rzecz innej osoby czynności mających wartość materialną lub niematerialną, w sposób powtarzający się, z reguły pod kierownictwem podmiotu organizującego proces pracy,

9 Z. Salwa, Prawo pracy, Warszawa 1994, s. 10. 
z tym, że oparta jest na zgodnym oświadczeniu woli pracodawcy oraz pracownika i wykonywana jest na ryzyko pracodawcy za wynagrodzeniem ${ }^{10}$. Prawo pracy, wraz z postępem gospodarczym i społecznym, stało się dziedziną regulującą wiele aspektów związanych z zatrudnieniem, a także część stosunków ściśle powiązanych z procesem świadczenia pracy. Mimo że domeną prawa pracy są stosunki prawno-pracownicze, ze względu na rosnącą rolę zatrudnienia niepracowniczego, prawo pracy coraz częściej reguluje elementy ochrony osób zatrudnionych na podstawie umów cywilnoprawnych.

Powszechnie akceptowany jest fakt, że oprócz kilku przypadków znaczącego wkładu z innych regionów podstawa dwudziestowiecznego prawa pracy została opracowana w Europie Zachodniej jako reakcja zarówno na negatywne skutki rewolucji przemysłowej, jak i łamanie praw robotników oraz nadużycia prawa cywilnego ${ }^{11}$. U podłoża prawa pracy leży uznanie faktu, że ścisła równość prawa cywilnego może prowadzić do niemożliwych do zaakceptowania sytuacji, w których strony umowy dotyczącej wymiany pracy na wynagrodzenie nie dysponują porównywalną siłą przetargową. Prawo pracy odbiega od podstawowego założenia prawa cywilnego, że żadna strona nie może skarżyć się na nieuczciwość warunków umowy, na której zawarcie zgodziła się dobrowolnie. Zamiast tego celem prawa pracy jest zapewnienie, aby żadnemu pracodawcy nie było wolno narzucać - a żaden pracownik nie był zmuszony do przyjęcia - warunków pracy gorszych niż te, które uznaje się za godziwą podstawę w danym społeczeństwie i czasie. Tak więc nie jest ono jedynie sposobem regulacji wymiany pomiędzy pracą a kapitałem, tak jak czyni to prawo cywilne w odniesieniu do umów cywilnych lub handlowych; jest ono raczej podstawowym środkiem operacjonalizacji tego, co Międzynarodowa Organizacja Pracy (MOP) określa współcześnie jako „godną pracę” i co wraz z ochroną pracowników wymaga uszanowania demokracji we wszystkich stosunkach, uwzględniając stosunki w miejscu pracy ${ }^{12}$.

Współczesne prawo pracy czerpie z różnych źródeł, wśród których można wyróżnić pięć głównych kategorii: konstytucję, akty międzynarodowe, ustawy, układy zbiorowe pracy i prawo zwyczajowe. O ile pierwsze trzy kategorie mają charakter powszechny i wynikają z porządku prawnego, kształtowanego przez władzę ustawodawczą, o tyle układy zbiorowe pracy i porozumienia mają charakter źródeł specyficznych tylko dla prawa pracy. Miały one ogromne znaczenie dla postępu prawa pracy, zwłaszcza w drugiej połowie XX w., dzięki rozwojowi układów zbiorowych pracy na wszystkich szczeblach od zakładowego, poprzez branżowy i regionalny, na krajowym skończywszy. Znaczenie układów zbiorowych pracy jako metody regulacji uprawnień w zakresie warunków pracy i płacy odgrywało w krajach europejskich ogromną rolę, choć różniło się w poszczególnych krajach - intensywny rozwój układów i porozumień obserwujemy

10 L. Florek, Prawo pracy, Warszawa 2005.

11 Na przykład, prawa pracy i socjalne po raz pierwszy zostały umieszczone w Konstytucji Meksyku w 1917 r.; bardzo możliwe, że wpłynęło to na Konstytucję MOP z 1919 r. W Europie po raz pierwszy uprawnienia socjalne i pracy uwzględniono w Konstytucji Republiki Weimarskiej w 1919 r.

12 J. Męcina, Social Dialogue in Face of Changes on the Labour Market in Poland. From Crisis to Breakthrough, Budapest-Warszawa 2017. 
w krajach skandynawskich, w Belgii czy Niemczech, z kolei w krajach Europy Środkowo-Wschodniej, w tym w Polsce, ich znaczenie w zasadzie jest niewielkie, poza kilkoma branżami skoncentrowanymi wokół kapitału państwowego. Mimo że każdy z krajów ma określoną specyfikę ze względu na warunki społeczne, ekonomiczne, organizacyjne i finansowe, a instytucjonalne ramy i charakter wzajemnych stosunków są wypadkową procesów społeczno-ekonomicznych, walki politycznej i tradycji kulturowej, można wyróżnić najważniejsze czynniki wyznaczające zachowania partnerów społecznych. Ich rola w krajach europejskich wzrasta poprzez udział i zaangażowanie partnerów społecznych w różne formy zinstytucjonalizowanego dialogu społecznego i aktywną rolę w uzgadnianiu wielu kwestii z zakresu polityki gospodarczej i polityki społecznej, a zwłaszcza stosunków pracy i rynku pracy ${ }^{13}$. Ich priorytetem jest oddziaływanie na takie elementy systemu, jak prawo pracy, system ubezpieczeń i zabezpieczenia społecznego, system konsultacji i negocjacji płacowych, prawo układowe i spory zbiorowe, polityka rynku pracy i przeciwdziałanie bezrobociu, system edukacji i kształcenia zawodowego, poziom rozwoju technologicznego, wzory uczestnictwa w życiu publicznym. Wraz $\mathrm{z}$ dynamicznymi zmianami na rynku pracy obserwujemy liczne inicjatywy na rzecz reformowania prawa pracy, charakterystyczne zarówno dla inicjatyw krajowych, jak też poziomu Unii Europejskiej. Ostatnie dekady to z jednej strony regulowanie nowych instytucji ochrony na wypadek zwolnień grupowych i restrukturyzacji zatrudnienia, transferu przedsiębiorstwa, pracy tymczasowej, $z$ drugiej strony to inicjatywy związane $\mathrm{z}$ deregulacją prawa pracy, zapisane w ustawodawstwach europejskich i krajowych. Charakterystyczną cechą rozwoju prawa pracy jest próba mierzenia się i nadążania za realnymi zjawiskami na rynku pracy, takimi jak poszerzanie się sfery zatrudnienia niepracowniczego, outsourcing pracy, samozatrudnienie. Polska wraz z transformacją społeczno-gospodarczą, a następnie integracją europejską, podążała w kierunku reformowania i gruntownej przebudowy prawa pracy, które odbywały się przede wszystkim pod wpływem procesów dostosowawczych i implementacji prawa europejskiego. Realne problemy związane z wysokim bezrobociem, nową strukturą gospodarki opartą na sektorze małych i średnich przedsiębiorstw (MŚP) i samozatrudnieniu generowały jednak dość drastyczne pogarszanie się jakości pracy, prowadząc do zjawiska segmentacji na rynku pracy. Mimo że zatrudnienie niepracownicze jest potrzebnym segmentem nowoczesnego rynku pracy, odpowiadającego na potrzeby mikroprzedsiębiorstw, jego rozmiary przybrały niepokojące rozmiary, co stało się przesłanką do zmian w ustawodawstwie pracy. Polska podjęła też dwukrotnie w okresie ostatniej dekady próbę rekodyfikacji prawa pracy, wypracowując zupełnie nowe projekty indywidualnego i zbiorowego prawa pracy.

13 J. Gardawski, Dialog społeczny w Polsce. Teoria, historia, praktyka, Warszawa 2009. 


\section{Próba kodyfikacji prawa pracy i jej wstępna ocena}

Ostatnią znaczącą inicjatywą było powołanie w 2016 roku Komisji Kodyfikacyjnej Prawa Pracy, której celem było opracowanie w ciągu 18 miesięcy projektów indywidualnego i zbiorowego prawa pracy. Nie trzeba przekonywać, że 18-miesięczny okres pracy nad dwoma poważnymi projektami, indywidualnego i zbiorowego prawa pracy, to okres zbyt krótki, aby powstał do końca przemyślany projekt, który rzecz jasna zawierając wiele kompromisów, stanowiłby całościowe spojrzenie na materię prawa pracy. Mimo doświadczeń z pierwszej próby kodyfikacji na początku lat 2000 i zebrania licznych doświadczeń doktryny, judykatury, praktyki i przedstawicieli partnerów społecznych, w tak krótkim okresie udało się wypracować ekspercką zaledwie propozycję, która wymaga jeszcze dużego wysiłku strony rządowej i ekspertów oraz partnerów społecznych, aby zyskała cechy wyważonego projektu legislacyjnego. Poprzednie doświadczenia z próby kodyfikacji wskazują, że bez rzetelnej ewaluacji tych propozycji przez pracodawców i związki zawodowe, bez oceny ewentualnych skutków społecznych i ekonomicznych, wreszcie bez debaty publicznej, która wyjaśni nowe rozwiązania i uzasadni ich wprowadzenie, będziemy mieć do czynienia z nieskoordynowaną akcją przypadkowego informowania (nie zawsze rzetelnego) i krytykowania przeważnie zbyt jednoznacznego, w miejsce ważenia interesów pracowniczych i gospodarczych. Wierząc w taką debatę i odpowiedzialność, jako uczestnik prac nad nowymi kodeksami pracy, przedstawiam swoje przemyślenia, uwagi i zastrzeżenia, mając nadzieję na ich wykorzystanie. Popierając projekty, jako podstawę dalszych prac i konsultacji, odnoszę się w mojej analizie do uwag i zastrzeżeń ogólnych, wyeksponowania dobrych propozycji oraz tych, które osobiście oceniam krytycznie lub wprost traktuję jako złe lub niesatysfakcjonujące rozwiązania, zgłaszając je w większości już na etapie prac naszej komisji. Warto przede wszystkim podkreślić, że projekt kodeksu pracy, oprócz dopasowania do standardów europejskich i krytycznego przeglądu przepisów funkcjonujących, służył realizacji kilku głównych postulatów:

- wprowadzenia rozwiązań minimalizujących zjawisko zatrudniania na podstawie tzw. umów zlecenia, w zamian za wprowadzenie elastycznych typów umów o pracę dotyczących prac krótkoterminowych, co niestety może budzić kontrowersje w zakresie osiągnięcia dostatecznej elastyczności stosunków pracy. Z jednej strony interesująco wyglądają nowe formy zatrudnienia (praca dorywcza, sezonowa, nieetatowa), ważne jest też znaczące wydłużenie umowy na okres próbny, z drugiej strony zaś mamy drastyczne skrócenie i ograniczenie stosowania umów terminowych do 18 miesięcy, przy jednoczesnym braku mocniejszego zróżnicowania ochrony ze względu na okres zatrudnienia, co może okazać się ryzykowne w warunkach pogorszenia się sytuacji na rynku pracy i wymaga oceny z perspektywy rynku pracy;

- wprowadzenia rozwiązań prawnych, pozwalających na odstępowanie od przepisów kodeksu na podstawie układów zbiorowych pracy i lepszego prawa układowego - to od dawna formułowany postulat, który niestety ze względu na zastrzeżenia 
do kształtu zbiorowego prawa pracy może okazać się regulacją nieefektywną. Po pierwsze, zbyt skomplikowane prawo związkowe może zniechęcać pracodawcę do rokowań z delegatem związkowym, który może nie być pracownikiem zakładu. Po drugie, zapisy wymuszające na pracodawcy rokowania zbiorowe należy uznać za niefortunne. Wreszcie po trzecie, wciąż zbyt mała przestrzeń dla materii układowej, która mogłaby się rozwijać także w zakładach pracy niezrzeszających związków zawodowych (ramowe układy zbiorowe pracy zawierane na poziomie Rady Dialogu Społecznego (RDS), przyjmowane na podstawie decyzji pracodawcy) - to przykładowe deficyty projektów, które powinny zostać uzupełnione i skorygowane na kolejnym etapie prac na forum RDS z udziałem ekspertów strony rządowej i partnerów społecznych;

- wprowadzenia rozwiązań odformalizowujących stosowanie prawa pracy u pracodawców małych, zdefiniowanych jako zatrudniających do 10 pracowników, choć jest dobrym kierunkiem, wydaje się, że mogłoby zostać rozszerzone, przynajmniej w pewnym zakresie, na pracodawców większych, np. zatrudniających do 50 pracowników - rezultat ten częściowo jest widoczny w zaprojektowanych przepisach o czasie pracy;

- wprowadzenia rozwiązań mających na celu istotne zwiększenie elastyczności w zakresie czasu pracy, w szczególności w stosunku do pracowników wykonujących prace trudne do zaplanowania, wykorzystanie opcji opt-out, dłuższe okresy rozliczeniowe, nowe zasady liczenia doby pracowniczej to korzystne rozwiązania, poddane jednocześnie kontroli związkowej, ale zbyt słabo jeszcze powiązane z przepisami dotyczącymi wynagrodzeń.

Myślę, że dzięki wnioskom partnerów społecznych przepisy te uda się jeszcze udoskonalić i dostosować do warunków zakładu pracy, nie ulega jednak wątpliwości, że dzięki pracom Komisji Kodyfikacyjnej dysponujemy usystematyzowanym katalogiem propozycji, które lepiej odpowiadają nowym potrzebom gospodarki niż obecnie funkcjonujące. Warto jednak podkreślić, że projekt ten, nie będąc projektem w ramach sformalizowanego procesu legislacyjnego, nie odnosi się do skutków finansowanych jego wprowadzenia. Tymczasem oprócz wprost zapisanych uprawnień, daleko idących zmian w zakresie domniemania stosunku pracy czy zasad wypowiadania i rozwiązywania umów o pracę, wprowadzone nowe procedury czy zasady ochrony będą generować koszty i wpływać bezpośrednio na warunki prowadzenia działalności gospodarczej, koszty zmian organizacyjnych czy restrukturyzacji. Inną ważną kwestią wymagającą uregulowania jest materia ubezpieczeń społecznych. To z tego punktu widzenia należy rozpatrywać dobre propozycje ograniczenia kosztów pracodawców w zakresie wypłaty wynagrodzenia chorobowego i przesunięcie ciężaru wypłaty świadczeń na system ubezpieczeń społecznych, co powinno promować zatrudnienie. Konieczne jest też ustalenie, czy w stosunku do osób wykonujących obecnie tzw. zatrudnienie na umowach o świadczenie usług zmianie ulegną zasady ubezpieczenia społecznego, wreszcie jak potraktujemy zasady zatrudniania w ramach pracy nieetatowej uczącej się młodzieży oraz osób pobierających świadczenia emerytalne w zakresie obowiązku ubezpieczenia? 
Trudno sobie wyobrazić przyjęcie zasad powszechnych w sytuacji poszukiwania bodźców do zachowania elastyczności w stosunkach pracy i zwiększania aktywności zawodowej Polaków. Wymuszenie zatrudnienia pracowniczego w stosunku do powyższych grup zmienia bowiem ich sytuację ubezpieczeniową, ale z punktu widzenia gospodarki i dorabiających (niezatrudnionych w ramach umowy na czas określony lub nieokreślony) studentów czy emerytów koniczne jest wypracowanie szczególnych zasad. W tym miejscu należy jednak podkreślić, że propozycje komisji wytyczają pożądany kierunek zmian, które wymagają dyskusji i oceny skutków regulacji.

Projekt kodeksu proponuje bardzo zdecydowaną promocję zatrudnienia pracowniczego, w kontekście powszechnego nadużywania tzw. zatrudnienia na umowach prawa cywilnego. Powyższe polega na mechanizmie domniemania stosunku pracy, w przypadku prac wykonywanych w ramach struktur organizacyjnych, na tzw. przerzuceniu ciężaru dowodu na pracodawcę w sprawach o ustalenie istnienia stosunku pracy oraz na domniemaniu zatrudnienia pracowniczego w przypadku wątpliwości co do tego, czy osoba świadczy usługi czy jest zatrudniona. Projekt kodeksu moderuje jednak skutki domniemania przez wprowadzenie katalogu form zatrudnienia, które według wyboru stron będą mogły być wykonywane bądź w postaci zatrudnienia pracowniczego, bądź samozatrudnienia. Proponuje, aby skutki ustalenia istnienia stosunku pracy ograniczyć w czasie do 12 miesięcy przed wniesieniem pozwu. Przepisy te zmieniają wymiar stosunków pracy w Polsce, realizując z jednej strony ochronę pracowników, ale z drugiej oddziałując też na warunki prowadzenia działalności gospodarczej. W powiązaniu z innymi propozycjami w zakresie stosowania umów zawartych na czas określony mocno ingeruje w rynek pracy i jako taki wymaga kompromisu partnerów społecznych. $\mathrm{Z}$ jednej strony proponuje się, aby umowy takie były zawierane wyłącznie wtedy, gdy istnieje obiektywnie okresowe zapotrzebowanie na pracę lub jeżeli uzasadniają to interesy pracownika. Z drugiej strony proponuje się skrócenie okresów wypowiedzenia oraz ograniczenie tzw. szczególnej ochrony w przypadkach, w których wypowiedzenie dokonywane jest na skutek ustania celu zawarcia umowy na czas określony. Proponuje się także ograniczenie czasu trwania umów zawartych na czas określony z powodu niepewności zatrudnienia do 18 miesięcy, zezwalając zarazem, aby układ zbiorowy pracy mógł wydłużać powyższy okres. Powyższe ograniczenie nie dotyczy jednak umów, które z powodów szczególnych mogą być obecnie zawierane na okresy dłuższe. W tych przypadkach nie obowiązuje bowiem ani limit czasu trwania takich umów, ani ograniczenie co do wielokrotności ich zawierania. Mechanizm domniemania oceniam jako zbyt daleko idący. Zdanie o tym, że praca wykonywana w strukturach jednostki organizacyjnej zatrudniającego jest wykonywana na podstawie umowy o pracę, prowadzi do likwidacji przypadków wykonywania pracy w innych formułach, zwłaszcza przy restryktywnej wykładni, np. Państwowej Inspekcji Pracy (PIP). Dlatego przepisy te wymagają jeszcze oceny partnerów i konsultacji oraz rozważenia ich powiązania z koncepcją kontraktu jednolitego, wprowadzającego daleko idące zróżnicowanie uprawnień i ochrony pracownika w zależności od zakładowego stażu pracy. 
Bardzo ważną i od dawna postulowaną propozycją, która pozwalałaby w warunkach coraz powszechniejszej cyfryzacji i informatyzacji procesów pracy szerzej wykorzystać pracę zdalną i na odległość, jest odformalizowanie regulacji dotyczących telepracy oraz wprowadzenie rozwiązań pozwalających na okazjonalne wykonywanie pracy na odległość, poprzez liberalizację stosowania przepisów dotyczących BHP w przypadku wykonywania prac krótkoterminowych poza placówką zatrudnienia. Chodzi przy tym o to, aby obowiązki z zakresu BHP były adekwatne do rzeczywistego ryzyka. Jednak już w przypadku pracy zdalnej nałożono nieuzasadniony limit takiej pracy do jednego dnia w tygodniu. Niestety, nie udało się w tak krótkim czasie konstruktywnie podejść do uberyzacji stosunków społecznych i gospodarczych, co stanowi cały czas wyzwanie dla zmieniającego się rynku usług i nie może pozostać bez jakiejkolwiek interwencji prawa pracy, choć jest niezwykle trudne.

W przypadku poddania projektu kodeksu dalszym pracom legislacyjnym należy uwzględnić potrzebę dostosowania do niego innych przepisów prawa. Dotyczy to, na co zwraca się uwagę w uzasadnieniu, co najmniej dwóch ważnych sfer. Po pierwsze, przepisów prawa gospodarczego publicznego w zakresie zdefiniowania przedsiębiorcy. Promowanie przez projekt kodeksu zasady, zgodnie z którą praca zarobkowa wykonywana jest przez pracowników i samozatrudnionych, wymaga wprowadzenia racjonalnych rozwiązań, z których będzie wynikać, kto z obecnych tzw. zleceniobiorców będzie przedsiębiorcą, a kto nie, oraz kto będzie przedsiębiorcą zarejestrowanym, a kto nie. Komisja zaproponowała wprowadzenie do treści projektu kodeksu dyrektywy interpretacyjnej, zgodnie z którą przy wykładni przepisów prawa pracy należy stosować w szczególności zasadę proporcjonalności, uwzględniając przede wszystkim prawo do pracy, wolność prowadzenia działalności gospodarczej, a także potrzebę realizacji celów społecznych. Powyższe ma na celu zaakcentowanie, że prawo pracy nie jest prawem służącym ochronie interesów jednej z grup społecznych, ale prawem ważenia praw i wolności zatrudnionych i zatrudniających. Nie ma także powodu, aby twierdzić, że prawa pracownicze są z założenia ważniejsze niż prawa przedsiębiorców. W procesie wykładni prawa sądy będą więc miały obowiązek stosowania konstytucyjnych reguł interpretacyjnych. Zbyt znacząca liczba klauzul generalnych powoduje jednak, że prawo staje się sporne i zależy w praktyce od woli i wyobraźni interpretatora, na przykład art. 48 projektu, który usuwa domniemanie stosunku pracy „przy wykorzystaniu unikalnych narzędzi lub stosowaniu wiedzy specjalistycznej”, czy art. 79, używając w ogólnym kontekście pojęcia „niepewności”. Takie techniki legislacyjne zapraszają adresatów projektowanych norm prawnych do sporu w zakresie ich wykładni i mogą prowadzić nie tylko do zwiększania ryzyka działalności gospodarczej, lecz także do licznych konfliktów. W nawiązaniu do omawianego problemu uregulowania samozatrudnienia $\mathrm{w}$ projekcie zaproponowano wprowadzenie pojęcia samozatrudnionego, czyli osoby zarobkującej przez pracę wykonywaną bez kierownictwa. Zapis ten nie oznacza jednak, że samozatrudniony musi być zawsze przedsiębiorcą, co jest domeną prawa gospodarczego, a więc w konsekwencji nie znamy materii, którą przyszło nam uregulować. $W$ projekcie zaproponowano uregulowanie podstawowych praw samozatrudnionych wykonujących pracę w ścisłym związku z określonym kontrahentem. 
Osobom takim - zwanym samozatrudnionymi ekonomicznie zależnymi - proponuje się m.in. elementarną ochronę stabilności zatrudnienia, minimalne stawki godzinowe, ograniczenie czasu świadczenia usług oraz okresy niewykonywania usług z zachowaniem prawa do wynagrodzenia. Należy podkreślić jednak, że nie w każdym przypadku miarą działalności jest czas świadczenia usług. W ten sposób regulacje te bez odpowiednich wyłączeń nie będą przystawać np. do działalności prowizyjnej typu sprzedaż i dystrybucja. Przedmiotowe propozycje zapisów wymagają ewaluacji ich stosowania, jak to miało miejsce przy procedowaniu ustawy o minimalnej stawce godzinowej, gdzie wyłączono pewne sfery działalności spod regulacji ustawy.

Ważnym dokonaniem projektu jest propozycja istotnej zmiany w kontekście regulacji dotyczących równości i zakazu dyskryminacji. Przede wszystkim projekt porządkuje obecny chaos dotyczący regulacji dyskryminacyjnych. Jednocześnie precyzuje się treść zasady równości (niebędącej dyskryminacją) oraz rozciąga ją na pracodawców ściśle ze sobą powiązanych, co budzi już moje poważne obawy. Celem powyższej regulacji jest zapobieżenie praktykom, polegającym na tworzeniu odrębnych pracodawców w celu różnicowania sytuacji prawnej pracowników, choć ich sytuacja faktyczna nie uległa zmianie. Mimo że w uzasadnieniu wskazuje się, iż celem regulacji nie jest wprowadzenie zasady identyczności, a jedynie równości, a podmioty powiązane będą więc miały pełne prawo do różnicowania warunków zatrudniania, jeżeli potrzeba taka będzie wynikała z powodów obiektywnych (miejsce wykonywania pracy, warunki jej wykonywania, zakres obowiązków i odpowiedzialności czy intensywność), to jednak konieczna jest ewaluacja tych przepisów i rzetelna analiza wszystkich obiektywnych przesłanek. Nieprzemyślana do końca regulacja może spowodować ogromne koszty po stronie pracodawców oraz nieuzasadnione konflikty w stosunkach pracy.

Projekt kodeksu w zakresie czasu pracy oceniam wysoko, podkreślając, że proponuje się wiele modyfikacji i zmian, których celem jest z jednej strony objęcie kategorią czasu pracy części okresu podróży służbowych oraz dyżurów w miejscu wyznaczonym przez pracodawcę, a z drugiej strony poszukiwanie rozwiązań elastycznych, ale w zakresie społecznie uzasadnionym. Wdrożenie pierwszego z celów oznacza, niestety, wprowadzenie dość skomplikowanych rozwiązań prawnych, z uwagi na to, że pełne zrównanie czasu podróży służbowych i różnych kategorii dyżurów z innymi okresami pozostawania w dyspozycji pracodawcy oznaczałoby bardzo znaczne podniesienie kosztów wynagrodzeń. Sposób ujęcia przez przepisy problemu wydaje się zbyt skomplikowany normatywnie. Przykładem jest art. 305 projektu o podróży służbowej. Wliczanie do czasu pracy całej podróży, przy czym w jej części poza godzinami pracy bez zachowania prawa do wynagrodzenia, stanowczo komplikuje normatywny obraz. Stanowczo jaśniejszym mechanizmem jest niewliczanie do czasu pracy podróży poza godzinami pracy z gwarantowanym prawem do odpoczynku. Nie umniejsza to jednak wysokiej oceny tego działu, który lepiej implementuje prawo europejskie, wprowadzając wiele nowych instytucji w zakresie okresów rozliczeniowych, opcji opt-out, pracy zespołowej, kont wynagrodzeń. 
Projekt kodeksu zawiera też bardzo rozległe i nowoczesne regulacje dotyczące pozasądowego rozwiązywania sporów pracowniczych. Proponuje on wprowadzenie ulgi w zakresie opłat sądowych dla tych pracodawców, którzy powołają komisje pojednawcze lub ustalą procedury mediacyjne. Projekt kodeksu mówi także o ulgach w ponoszeniu kosztów sądowych wobec pracowników, którzy zdecydują się na skorzystanie z drogi polubownego rozwiązania sporu z pracodawcą. Proponuje się także wprowadzenie rozwiązań pozwalających na uwzględnianie przez pracodawców roszczeń pracowniczych na skutek wewnętrznego odwołania od decyzji pracodawców dotyczących wypowiedzenia lub rozwiązania umowy o pracę. Projekt kodeksu promuje ugody pozasądowe, a w zakresie wynagrodzeniowym - rozstrzyganie sporów przez komisje arbitrażowe. Te dobre rozwiązania wymagają jednak debaty partnerów społecznych na temat szczegółowych procedur i warunków wspierania procesu mediacji i arbitrażu przez instytucje dialogu społecznego.

Mimo interesującego dorobku zbiorowego kodeksu pracy, poważnego wkładu w uporządkowanie instytucji przedstawicielstwa związkowego, układów zbiorowych pracy i regulaminów, bardzo dobrej części regulującej rozwiązywanie sporów zbiorowych, projekt ten wymaga znacznego uproszczenia, przedyskutowania w gronie partnerów społecznych wielu instytucji, wreszcie poważnej debaty o warunkach rozwoju prawa układowego w Polsce. Mnożenie instytucji przedstawicielskich nie zwiększy uzwiązkowienia, nie wpłynie też motywująco na pracodawców w zakresie rozwijania rokowań układowych. Ten ciekawy, ale niestety nieadaptowalny wprost projekt wymaga jeszcze większego zaangażowania partnerów społecznych. Tylko wtedy możliwe będzie wypracowanie rozwiązań, które będą budować relacje zbiorowe i wpłyną na rozwój dialogu autonomicznego.

\section{Podsumowanie}

Krótki, a właściwie ekspresowy, jak na tak złożoną materię, czas na prace nad projektami kodeksu ma ten skutek, że walorem projektów przygotowanych przez Komisję Kodyfikacyjną, odwołując się wprost do uzasadnienia, jest przede wszystkim wskazanie konstrukcji prawnych. Niektóre parametry powyższych instytucji lub niektóre przesłanki merytoryczne powinny być jednak uzupełnione w dyskursie z partnerami społecznymi, wymagają bowiem rzetelnej ewaluacji i oceny. Odnosząc się zaś do kwestii merytoryczno-technicznych, można wskazać, że zbyt daleko idąca kazuistyka prawna powoduje miejscami znaczący spadek poziomu komunikatywności przepisów, których adresatami są przede wszystkim ludzie pracy, a zatem język i struktura powinny być przejrzyste, co oznacza pewien kolejny wysiłek, którego wymagają projekty. Nie ulega jednak wątpliwości, że dorobek Komisji Kodyfikacyjnej jest na tyle znaczący i interesujący z perspektywy realizacji od lat zgłaszanego postulatu uchwalenia nowego Kodeksu pracy, lepiej odpowiadającego na wyzwania współczesności i przyszłości, że warto podjąć wysiłek dalszych prac. Brak politycznej woli rozpoczęcia procesu konsultacji projektu wymaga zaadresowania tego 
postulatu do partnerów społecznych. Tylko na tej drodze projekty, wymagające jeszcze doprecyzowania, korekty i ewaluacji niektórych propozycji, projekty, które budzą dziś obawy jednej i drugiej strony stosunków pracy, mogą stać się mniej kontrowersyjne i na tyle atrakcyjne dla współczesnych wyzwań rynku pracy, że pojawi się polityczna wola dokończenia nad nimi prac legislacyjnych.

\section{Bibliografia}

Anioł W., Polityka spoteczna, Warszawa 2018.

Bronstein A., International and comparative Labour Law, Current Challenges, Switzerland 2009. Florek L., Prawo pracy, Warszawa 2005.

Gardawski J., Dialog spoteczny w Polsce. Teoria, historia, praktyka, Warszawa 2009.

Gardawski J. (red.), Polacy pracujacy a kryzys fordyzmu, Warszawa 2009.

Gardawski J., Świat pracy a fordyzm i post fordyzm, w: Polacy pracujący a kryzys fordyzmu, J. Gardawski (red.), Warszawa 2009.

Komisja Europejska, Transformation of labour and future of labour law in Europe, final report, Brussels 1998.

Męcina J., Social Dialogue in Face of Changes on the Labour Market in Poland. From Crisis to Breakthrough, Budapest-Warszawa 2017.

Męcina J., Wplyw dialogu społecznego na kształtowanie się stosunków pracy w III RP, Warszawa 2011.

Morawski W., Globalizacja i praca. Kontekstowa analiza świata pracy, w: Przyszłość pracy w XXI wieku, S. Borkowska (red.), Warszawa 2004.

Salwa Z., Prawo pracy, Warszawa 1994. 